\title{
Modernizar e disciplinar em nome da saúde pública
}

\author{
Modernization and discipline in the name of public health
}

Modernizar y disciplinar en nombre de la salud pública

\begin{abstract}
MODERNIZAR A ORDEM EM NOME DA SAÚDE: A SÃO PAULO DE MILITARES, POBRES E ESCRAVOS (1805-1840). Mantovani R. Rio de Janeiro: Editora Fiocruz; 2017. 276 p. ISBN 978-85-7541-494-1
\end{abstract}

doi: 10.1590/0102-311X00097818

A historiografia sobre a cidade de São Paulo, Brasil, apresenta como uma das suas principais lacunas o reduzido número de estudos que focam a urbe na primeira metade do século XIX. Nota-se que a preferência dos pesquisadores recai sobre o período posterior a 1840, quando a capital dos paulistas e o porto de Santos afloravam como os dois principais polos de negociação e exportação do café que, a partir de então, tornou-se a fonte central do enriquecimento regional.

O livro assinado por Mantovani adota como balizas temporais os anos de 1805, quando a cidade passou a ser alvo de intervenção oficial mais consistente, e 1840, momento no qual a cidade iniciava o processo que, baseado na economia do café, a transformaria décadas depois na segunda maior metrópole do país. O empenho do autor em analisar esse período faz sua obra se situar como um desdobramento do livro de Maria Luiza Marcílio ${ }^{1}$ que, na linha da demografia histórica, deu conta das transformações que marcaram a cidade a partir de 1750 . No entanto, diferentemente dessa, Mantovani centrou sua ótica na questão do ordenamento urbano sob a perspectiva sanitária, revelando a existência de uma noção de saúde pública que implicava o controle das enfermidades, prolongamento da vida e número de óbitos admissíveis para o bom funcionamento da comunidade paulistana. A redobrada atenção à cidade pelas lentes oficiais contava com vários motivos: a proximidade com o Rio de Janeiro, sede do poder colonial e posteriormente imperial, a contínua presença de viajantes estrangeiros na região e a posição estratégica de São Paulo na organização das expedições comerciais e militares que se dirigiam para as fronteiras do Sul. Em conjunto, essas circunstâncias impunham que a região reunisse condições para desempenhar um renovado papel no contexto brasileiro.

A operação realizada pelo autor tem como apoios teóricos os conceitos de "polícia médica" tal como foi elaborada na Alemanha e analisada por Rosen 2 e, sobretudo, nos ensinamentos de Foucault 3,4 sobre as pretensões da medicina social e dos dispositivos legais no processo de disciplinação do corpo social. Apesar das constantes referências a ambos os autores, Mantovani evita incorrer em um dos mais constantes vícios dos pesquisadores nacionais, o de não perceber o processo de adaptação local do ideário sanitário estrangeiro, contribuindo para a discussão da questão que pode ser sintetizada na interrogação “o que faz do Brasil, Brasil?”.

Além disso, o autor enfrentou o desafio referente à disponibilidade de fontes primárias sobre o tema abordado. Ele garimpou os raros jornais 
que circulavam na cidade no período privilegiado no estudo, os registros da Câmara Municipal e as anotações realizadas pelos visitantes da cidade, entrelaçando tais dados com o que estava sendo proposto no Rio de Janeiro pela comunidade médica e administrativa. Nesse processo, uma circunstância que chama a atenção do leitor é que, no caso paulistano em especial, a maior parte das decisões sanitárias não cabia aos médicos, mas sim aos políticos, militares e clérigos congregados na administração municipal. Não só havia pouco médicos em São Paulo, mas também eles usufruíam de escassos poder e prestígio social para intervir de forma mais consistente nas decisões sobre a saúde coletiva, apanágio que obteriam na segunda metade do século XIX, inclusive devido à ocorrência do que se convencionou denominar de "revolução pasteuriana". Por isso, o autor aponta que as decisões referentes à higiene pública despontavam como situações "desmedicalizadas".

A análise refere-se a uma cidade que era celebrada como uma área salubre - isto se comparada ao Rio de Janeiro - e que tinha como principais ameaças sanitárias a varíola, a hanseníase e as "febres paulistas". Nesse contexto, a administração pública inicialmente adotou as medidas sanitárias dispostas nas ordenações sanitárias lusitanas, da Fisicatura-mór e do Protomedicato e, em seguida, elaborando códigos de posturas, um em 1820 e outro uma década depois, os quais colocam em evidências que as leis pertinentes à saúde pública paulatinamente se tornaram mais minuciosas e exigentes, conferindo maior controle sobre o cotidiano coletivo e punindo os infratores com multas pecuniárias e prisão.

Um corpo burocrático cada vez mais extenso colocava em práticas as ações de "vigiar e punir", esquadrinhando a um só tempo o espaço físico e o tecido social. Exigia-se a drenagem dos pântanos, a derrubada das matas e a conservação dos caminhos da mesma maneira que a criação da Instituição Vacínica passou a impor a imunização coletiva contra o "mal de bexigas". A função do antigo Hospital Militar e a Santa Casa, mais do que cuidar dos doentes, consistia na retirada do convívio dos sadios os enfermos portadores de patologias que poderiam colocar em risco a saúde da população.

No mesmo ritmo, baseado nos princípios miasmáticos, segundo os quais os ambientes naturais ou criados pelo homem, se não bem administrados, poderiam gerar fluidos que "envenenavam” os ares e causavam as doenças coletivas. Os prédios passaram a ser mais intensamente fiscalizados, condenando-se à demolição os mais antigos e cobrando a atenção às posturas municipais na construção e ocupação das novas residências. $\mathrm{O}$ asseio dos espaços públicos despontava como uma das principais preocupações da administração paulistana, empregando-se para isto o trabalho dos prisioneiros, fato que era criticado pela elite ilustrada da cidade, representada, sobretudo, pelos estudantes da faculdade de Direito que tinha sido instituída em São Paulo por ordem real, em 1828.

Outras medidas que já estavam sendo implantadas na Europa, no entanto, apesar de discutidas em São Paulo antes de 1840, só ganharam concretude no período posterior. Dentre elas, destaca-se a criação do primeiro cemitério municipal, em 1858, com o objetivo de afastar os insalubres cadáveres da proximidade dos vivos, visto que um grande número de sepultamentos ocorria nos recintos das igrejas ou nas vizinhanças dos templos; já o matadouro e as oficinas de curtume só posteriormente foram realocados nas franjas do aglomerado urbano.

A admissão da população como riqueza de um país ganhava consistência nas ações administrativas. Para além de limpar, sanear e embelezar a cidade, havia a necessidade de um contingente urbano disciplinado, utilizando-se dentre outros recursos a imposição das leis atinentes à saúde pública. Nesse aspecto, São Paulo tendia ao caos: alçada da condição de vila à de cidade em 1711, no início do século XIX a urbe colocava em contato cotidiano um restrito contingente de brancos integrantes da elite, homens e mulheres pobres que sobreviviam de pequenos expedientes, uma comunidade de escravos, grupos de indígenas e visitantes dos mais diferentes extratos 
sociais, trazendo para o interior do espaço paulistano comportamentos regidos pelo "código do sertão", que geravam situações em que a violência e a morte eram eventos corriqueiros 5 .

Nesse encaminhamento, inspirado uma vez mais em Foucault, o autor coloca em evidências os múltiplos usos do projeto sanitário na administração da vida social sem, no entanto, aprofundar a questão constituída pela relação entre as iniciativas em prol da modernização urbana e o controle de uma população marcada pela heterogeneidade.

O mérito do livro de Mantovani está, sobretudo, em algo que até então pouco foi vistoriado pelos pesquisadores: a origem da ideia de saúde pública no território bandeirante. Nesses termos, a obra desponta não só como uma significativa contribuição para o entendimento da administração sanitária paulista nas primeiras décadas do século XIX e suas implicações na ordenação da vida coletiva, mas também como uma fonte preciosa para o entendimento mais aprimorado do pretérito bandeirante.
Cláudio Bertolli Filho 1

${ }^{1}$ Faculdade de Arquitetura Artes e Comunicação de Bauru, Universidade Estadual Paulista Júlio de Mesquita Filho, Bauru, Brasil.

cbertolli@uol.com.br

1. Marcílio ML. A cidade de São Paulo: povoamento e população, 1750-1850. São Paulo: Pioneira; 1973.

2. Rosen G. Da polícia médica à medicina social. Rio de Janeiro: Edições Graal; 1979.

3. Foucault M. Microfísica do poder. Rio de Janeiro: Edições Graal; 1979.

4. Foucault M. Vigiar e punir: nascimento da prisão. Petrópolis: Editora Vozes; 1977.

5. Franco MSC. Homens livres na ordem escravocrata. 3a Ed. São Paulo: Káiros; 1983. 